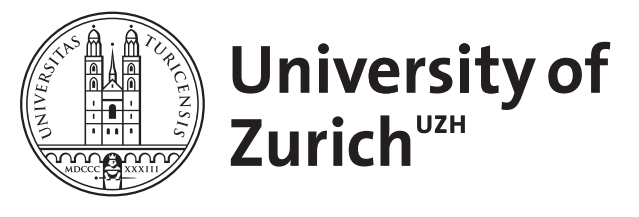

\title{
In vitro studies on odontogenic tumors
}

Catón, Javier ; Mitsiadis, Thimios A ; Morgan, Peter R

\begin{abstract}
Ameloblastomas are uncommon benign neoplasms of the jaws. They originate from dental epithelial cells, but they are not capable of mineralizing or forming enamel. The study of these tumors is limited to live tissue collected from patients during scheduled surgery. Ameloblastomas grow slowly in vivo and this property is translated to their behavior in vitro. Here, we describe the methods to culture ameloblastomas in organotypic cultures, as well as to isolate stem/progenitor cells from these tumors.
\end{abstract}

DOI: https://doi.org/10.1007/978-1-61779-860-3_15

Posted at the Zurich Open Repository and Archive, University of Zurich ZORA URL: https://doi.org/10.5167/uzh-68955

Journal Article

Originally published at:

Catón, Javier; Mitsiadis, Thimios A; Morgan, Peter R (2012). In vitro studies on odontogenic tumors. Methods in Molecular Biology, 887:167-177.

DOI: https://doi.org/10.1007/978-1-61779-860-3_15 


\section{Metadata of the chapter that will be visualized online}

\begin{tabular}{|c|c|c|}
\hline Series Title & \multicolumn{2}{|c|}{ Methods in Molecular Biology } \\
\hline Chapter Title & \multicolumn{2}{|c|}{ In Vitro Studies on Odontogenic Tumors } \\
\hline \multicolumn{3}{|l|}{ Chapter SubTitle } \\
\hline Copyright Year & \multicolumn{2}{|l|}{2012} \\
\hline Copyright Holder & \multicolumn{2}{|c|}{ Springer Science + Business Media, LLC } \\
\hline \multirow[t]{8}{*}{ Corresponding Author } & Family Name & Catón \\
\hline & Particle & \\
\hline & Given Name & Javier \\
\hline & Suffix & \\
\hline & Division & $\begin{array}{l}\text { Departamento de Anatomía y Embriología Humana I, Faculty of } \\
\text { Medicine }\end{array}$ \\
\hline & Organization & Universidad Complutense Madrid \\
\hline & Address & Madrid, Spain \\
\hline & Email & javicaton@med.ucm.es \\
\hline \multirow[t]{8}{*}{ Author } & Family Name & Mitsiadis \\
\hline & Particle & \\
\hline & Given Name & Thimios A. \\
\hline & Suffix & \\
\hline & Division & $\begin{array}{l}\text { Department of Orofacial Development and Regeneration, Faculty of } \\
\text { Medicine }\end{array}$ \\
\hline & Organization & Institute of Oral Biology, ZZM, University of Zurich \\
\hline & Address & Zurich, Switzerland \\
\hline & Email & \\
\hline \multirow[t]{8}{*}{ Author } & Family Name & Morgan \\
\hline & Particle & \\
\hline & Given Name & Peter R. \\
\hline & Suffix & \\
\hline & Division & Oral Pathology \\
\hline & Organization & King's College London Dental Institute \\
\hline & Address & London, UK \\
\hline & Email & \\
\hline
\end{tabular}

Abstract

Ameloblastomas are uncommon benign neoplasms of the jaws. They originate from dental epithelial cells, but they are not capable of mineralizing or forming enamel. The study of these tumors is limited to live tissue collected from patients during scheduled surgery. Ameloblastomas grow slowly in vivo and this property is translated to their behavior in vitro. Here, we describe the methods to culture ameloblastomas in organotypic cultures, as well as to isolate stem/progenitor cells from these tumors.

Key words: (separated by Ameloblastomas - Odontogenic tumors - Enamel - Organotypic culture - Tumor stem cells - Cell '-') cocultures 


\section{Author's Proof}

\section{In Vitro Studies on Odontogenic Tumors}

\section{Abstract}

Ameloblastomas are uncommon benign neoplasms of the jaws. They originate from dental epithelial cells, 5 but they are not capable of mineralizing or forming enamel. The study of these tumors is limited to live 6 tissue collected from patients during scheduled surgery. Ameloblastomas grow slowly in vivo and this 7 property is translated to their behavior in vitro. Here, we describe the methods to culture ameloblastomas 8 in organotypic cultures, as well as to isolate stem/progenitor cells from these tumors.

Key words: Ameloblastomas, Odontogenic tumors, Enamel, Organotypic culture, Tumor stem cells, 10 Cell cocultures

Odontogenic tumors (OTs) present considerable challenges for 13 any investigator willing to use cell and organotypic culture in stud- 14 ies with human tissue as the starting material. These challenges 15 could be summarized as follows:

1. The range and diversity of the tumors 17

2. The rarity of individual types of odontogenic tumors 18

3 . The frequent, although not exclusive, intra-osseous location of 19 these tumors

4. The diverse tissue composition of the odontogenic tumors 21

5 . The usually slow rate of the odontogenic tumors' growth 22

If due consideration is paid to these drawbacks, it is possible to 23 employ the tissue in experimental, not simply descriptive, 24 investigations. 


\section{Author's Proof}

The classification of OTs most used currently is based on that published in 2005 by the World Health Organization (WHO) (1), although unfortunately it introduced several somewhat arbitrary changes in terminologies from those in common use. Broadly, the benign OTs are classified along embryological lines according to whether neoplastic odontogenic epithelium appears to reflect interaction with odontogenic ectomesenchyme or not. One subgroup appears to represent neoplastic growth of tissues derived from the ectomesenchyme itself. Malignant OTs are generally classified descriptively according to their similarity to their benign counterparts.

Benign OTs represent a range of growth disorders from unequivocal neoplasms (e.g., ameloblastomas) to unequivocal hamartomas (compound and complex odontomas) with some entities having an intermediate status (e.g., adenomatoid odontogenic tumor). Parallels with normal tooth development break down with some tumors because these produce unique structures and/or cells not found in the developing teeth (e.g., ghost cells in the calcifying odontogenic cyst, now termed the calcifying cystic odontogenic tumor). These examples illustrate some of the range and diversity exhibited by OTs.

OTs are uncommon tumors. The most common unequivocal OT is the ameloblastoma, a locally aggressive benign neoplasm. Ameloblastomas represent less than 5\% of head and neck neoplasms. In the Afro-Caribbean ethnic group, they are more common and in parts of Africa they represent a significant proportion of untreated neoplasms. Controversially, in 2005, the WHO included a cyst, the odontogenic keratocyst, among odontogenic neoplasms, based upon molecular genetic criteria and its propensity for recurrence. This instantly made this cystic lesion the most common odontogenic neoplasm in ethnic Caucasian and Asians, but the status of this entity is still not settled (2). Adenomatoid odontogenic tumors and the odontomes are the next common OTs, after ameloblastomas, both manifesting in a younger population, the second decade. Ameloblastomas and odontogenic keratocysts peak in the fourth or fifth decades. Most other odontogenic tumors are very rare indeed and, unfortunately for the experimental scientist, usually inaccurately diagnosed preoperatively. The commonest malignant $\mathrm{OT}$ is the ameloblastic carcinoma, which is more rare than its benign counterpart. A compendium of incidence data for OTs is to be found in Reichart \& Philipsen (3).

Most OTs are intra-osseous, a minority of them arising in the gingiva (i.e., peripheral OTs). This makes for difficulties in accessing tumorigenic tissue for culture or banking fresh frozen samples. Band-saw slicing, appropriate for fixed hard tissues, is contraindicated in fresh specimens for reasons of infection control. However, the behavior of the tumors sometimes assists access. In those OTs that expand the jaws, typically large ameloblastomas, the normally dense cortical bone is thinned and can be prized open after slicing [AU2] 


\section{Author's Proof}

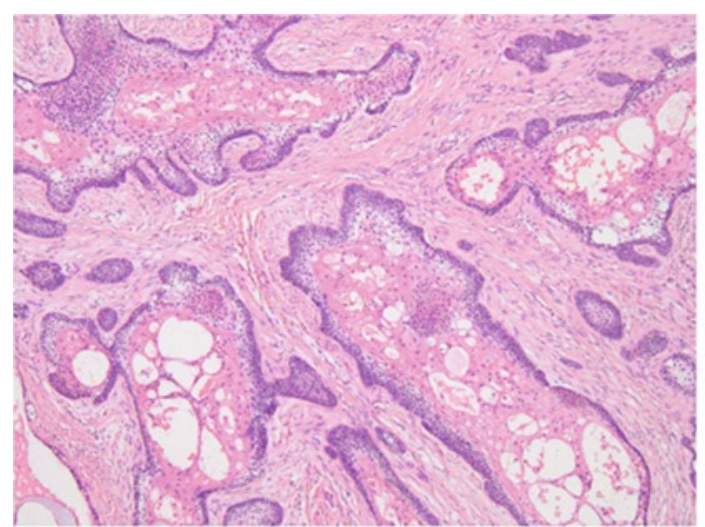

Follicular

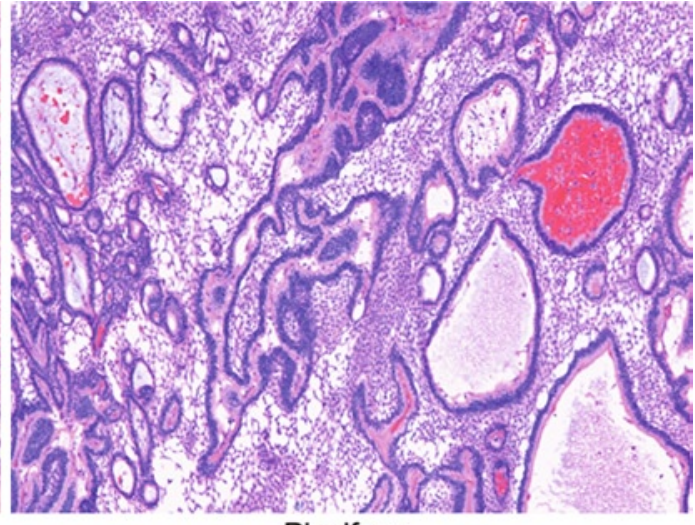

Plexiform

Fig. 1. H\&E sections of the two most common solid/multicystic ameloblastomas: Follicular and Plexiform.

with a scalpel to access the soft tumorigenic tissue. Samples taken in this way are less likely to be contaminated with oral microorganisms than those from tumors exposed to the mouth.

A feature of OTs that may pose a problem for diagnosis as well as constituting a disadvantage for cell studies is the extensive cystic change. This is well illustrated in most of the large ameloblastomas. As the neoplasm enlarges, multiple cystic spaces in the epithelial component (i.e., microcysts) and/or the delicate connective tissue (i.e., stromal cysts) expand and coalesce so that opening an expanded cortex reveals a space filled with straw-colored fluid. This is a frequent finding in the two commonest subtypes of ameloblastomas, the solid/multicystic (Fig. 1) and the unicystic variants. Incisional biopsies that include epithelium only from the expanded cyst wall hamper diagnosis, as it is thin and may not show classical features of the tumor and if this is the only material available for cell culture the epithelial cell yield is low.

Other OTs, such as the adenomatoid odontogenic tumor and calcifying odontogenic cyst, may present with a largely cystic expansion of the jaw. The odontogenic keratocyst, assuming we regard it as an OT, has the disadvantage from the perspective of cell culture of not expanding the jaw, or doing so only in juveniles or after a long period of neglect. On the other hand, odontogenic keratocysts are usually treated conservatively nowadays by the delicate detachment of the cyst wall from the inner surface of the jaw (i.e., endosteal), so experimental samples may be obtained direct from the surgeon or pathologist.

Apart from the rare and serendipitous presentation of many OTs, a further problem for cell culture and analytical studies is their heterogeneous nature. Particularly, the rarer OTs contain a mixture of hard and soft tissues. Where the hard tissue is a tooth or several discrete tooth-like elements, these may be removed before explanting or freezing the tissue, but some OTs have dispersed 


\section{Author's Proof}

dentine- or enamel-like hard tissues from which odontogenic epithelium, or even mesenchymal stroma, may be impossible to separate. Two of the most common tumors of this type are mature Pindborg tumors (i.e., calcifying epithelial odontogenic tumors) and the cementoblastoma, one category of OT of odontogenic ectomesenchymal origin consisting almost solely of mineralized tissue.

In the following, we describe methods for the culture of ameloblastoma explants taking into consideration the above difficulties for the collection of this tumor. We do not mention any ethical considerations on the understanding that each researcher will follow the protocols of the institution where the research will take place.

\section{Materials}

2.1. Cryopreservation

\subsection{Fixatives}

Tissue should arrive at the pathology department fresh. The tissue is divided for pathology, tissue bank, and research (see Note 1).

Liquid nitrogen is commercially available (see Note 2), and stored in liquid nitrogen dewars and liquid nitrogen storage containers. Cryo tubes, Cryo $1{ }^{\circ} \mathrm{C}$ Freezing Container such as "Mr. Frosty," and cryo-protectants such as glycerol or dimethyl sulfoxide (DMSO) for cellular cryopreservation.

Two different types of fixatives are routinely used: $10 \%$ neutral buffered formalin for pathological studies and $4 \%$ paraformaldehyde in $0.1 \mathrm{M}$ phosphate buffer $(\mathrm{PB})$ for research.

1. $10 \%$ Buffered formalin:

\begin{tabular}{lr}
\hline Formaldehyde $(37-40 \%)$ & $100 \mathrm{ml}$ \\
\hline Distilled water & $900 \mathrm{ml}$ \\
$\mathrm{NaH}_{2} \mathrm{PO}_{4}$ & $4.0 \mathrm{~g}$ \\
$\mathrm{Na}_{2} \mathrm{HPO}_{4}$ (anhydrous) & $6.5 \mathrm{~g}$ \\
\hline
\end{tabular}

Mix to dissolve. Store at room temperature.

2. $4 \%$ Paraformaldehyde in $0.1 \mathrm{M}$ phosphate buffer.

\begin{tabular}{lc}
\hline Paraformaldehyde & $40 \mathrm{~g}$ \\
\hline 0.1 M Phosphate buffer & $1,000 \mathrm{ml}$ \\
\hline
\end{tabular}

Heat to $60-65^{\circ} \mathrm{C}$ while stirring. Add a few drops of $1 \mathrm{~N} \mathrm{NaOH}$ until solution is clear. Continue to stir to dissolve. Cool the solution, filter, and aliquot (see Note 3 ). 


\section{Author's Proof}

2.3. Buffers

2.4. Tissue Sectioning and Staining

\subsection{Culture Media and Materials}

1. 0.2 M Phosphate buffer, $\mathrm{pH}$ 7.4.

\begin{tabular}{lr}
\hline $\mathrm{Na}_{2} \mathrm{HPO}_{4}$ & $21.8 \mathrm{~g}$ \\
$\mathrm{NaH}_{2} \mathrm{PO}_{4}$ & $6.4 \mathrm{~g}$ \\
\hline
\end{tabular}

Distilled water up to $1,000 \mathrm{ml}$.

2. 1 M Tris- $\mathrm{Cl}$ ( $\mathrm{pH} 7.4)$.

\begin{tabular}{lc}
\hline Tris base & $121.1 \mathrm{~g}$ \\
$\mathrm{HCl}$, concentrated & $70 \mathrm{ml}$ \\
\hline
\end{tabular}

t4.1

Distilled water up to $1,000 \mathrm{ml}$.

\begin{tabular}{lr}
\hline l M Tris-Cl & $100 \mathrm{ml}$ \\
0.5 M EDTA, pH 8.0 & $20 \mathrm{ml}$ \\
\hline
\end{tabular}

t5.1

t5.2

Distilled water up to $1,000 \mathrm{ml}$ (see Note 4). 145

4. HANKs (commercially available for cell culture). 146

5. PBS (commercially available for cell culture). 147

1. SuperFrost Plus glass slides or similar slides to increase adherence. 148

2. Microtome/cryostat and material related to their use. 149

3. Wax for embedding (purified paraffin/synthetic resin blend). 150

4. Xylene/Histoclear ( see Note 5). 151

5. Alcohol gradient, 50, 70, 80, 90, and 100\% (see Note 6). 152

6. Tissue-Tek CRYO-OCT Compound, Sucrose, cryo-embed- 153 ding molds, and $-80^{\circ} \mathrm{C}$ freezer. 154

7. Routine H\&E staining material.

1. Progenitor cell targeted to oral epithelium defined liquid cul- 156 ture medium (CnT24). 157

2. DMEM supplemented with $1 \times$ penicillin/streptomycin antibi- 158 otics for washing and tissue transport. 159

3. DMEM supplemented with $10 \%$ fetal calf serum (FCS) and $1 \times 160$ penicillin/streptomycin antibiotics for organotypic cultures. 161

4. Differentiation medium: BGJb medium supplemented with 162 $10 \mathrm{mg} / \mathrm{ml}$ ascorbic acid, $2 \mathrm{mM}$ of sodium $ß$-glycerophosphate, 163 and $1 \times$ penicillin/streptomycin antibiotics. 164

5. $2.4 \mathrm{U} / \mathrm{ml}$ of Dispase. 165

6. $0.25 \%$ Trypsin. 166

7. Cell and organ culture dishes, metal grids, and support filters. 167

1. Glass dish. 168

2. Forceps, scalpels, blades, and needles. 169 


\section{Author's Proof}

170

\section{Methods}

3.1. Tissue Extraction/ Preservation

\subsection{Tissue Selection}

3.3. Tissue for Research

\subsubsection{Fresh Tissue} for In Vivo Studies
Once surgery of the tumor has been scheduled, it is important to follow up with the surgical team. Most hospitals will have a service to bring the tissue to the pathology department (see Note 7), but it is recommended to collect it personally-if possible-to minimize the time from surgery to the laboratory.

A pathologist familiar with ameloblastomas should select an area of the tumor that will be likely to be richer in tumor cells. As mentioned in the introduction, some of these tumors could have very little starting material to work with. The tissue is then divided for pathology, tissue bank (see Note 8), and research. This methods chapter focuses only on the research portion.

The tissue selected for research should be divided:

\section{Flash freeze}

This is achieved by submerging the sample in liquid nitrogen or a mixture of dry ice and ethanol. This frozen tissue can be later used to extract nucleic acid for gene expression and genetic studies (qPCR, microarray, etc.).

2. Fixation

Although some tissue will be fixed using 10\% buffered formalin (see Note 9), most tissue for research should be fixed immediately by submerging it in $4 \% \mathrm{PFA}$ at $4^{\circ} \mathrm{C}$ overnight. The fixed tissue can be used for genetic studies (generally, we perform in situ hybridization, immunohistochemistry).

For in situ hybridization, cryosections are normally used.

\section{Cryoprotection}

After fixing, the tissue should be rinsed at room temperature in $0.1 \mathrm{M}$ phosphate buffer with $5 \%$ sucrose (this process will initiate the cryoprotection of the tissue). Continue with increasing concentrations of sucrose starting at $5 \%$ sucrose in phosphate buffer reaching $20 \%$ in $5 \%$ increments. Proceed for $30 \mathrm{~min}$ in each sucrose mixture at room temperature leaving it overnight at $4^{\circ} \mathrm{C}$ in fresh $20 \%$ sucrose/phosphate.

4. Infiltration

The tissue is then placed into an infiltration mixture $(2: 1,20 \%$ sucrose phosphate buffer and O.C.T. embedding medium) for $30 \mathrm{~min}$ at room temperature before freezing (see Note 10).

5. Embedding and freezing

Transfer the tissue to an embedding mold and fill the mold with fresh infiltration mixture. Rapidly submerge the mold into Isopentane cooled with liquid nitrogen (see Note 11). After the material is frozen, wrap the block and store at $-80^{\circ} \mathrm{C}$. 


\section{Author's Proof}

3.3.2. Fresh Tissue for In Vitro Studies
6. Sectioning 212

$3-5-\mu \mathrm{m}$ sections are cut at $-20^{\circ} \mathrm{C}$ in a cryostat. To achieve ideal sections, it is critical to have the knife-edge as sharp as possible. Trim the block face to a diamond shape, with the long axis oriented vertically. This orientation helps to make removal of the sections from the knife-edge easier, and will minimize handling damage of the tissue. Use a small camel hairbrush to guide the section off the block face and transfer it to glass slides (see Note 12). Allow the section to dry on the slide at room temperature. Store slides at $-80^{\circ} \mathrm{C}$ until needed.

Fresh tissue can be cultured in an organotypic form to maintain the architectural three dimensions of the tissue or in monolayer cell culture to isolate specific cells.

1. Organotypic cultures

Tissue is cut into $2-5-\mathrm{mm}$ cubes and placed into Trowell-type culture dishes (4). These cultures can be maintained for approximately 15 days using DMEM medium supplemented with $10 \%$ FCS. The tissue can be induced using proteins and/ or cell cocultures. The usage of beads for induction has the advantage of showing the effect in the precise site of application. Following are examples of induction beads and cell cocultures.

2. Induction beads

Affi-gel agarose $(75-150-\mu \mathrm{m}$ diameter $)$ or heparin acrylic beads (100-200 mesh/100-250- $\mu$ m diameter), depending on the type of proteins, are needed for induction. Ameloblastomas are induced with proteins involved in tooth development. Recombinants are diluted with $0.1 \%$ bovine serum albumin (BSA) in PBS, pH 7.4, to concentrations of 100-200 ng/ $\mu \mathrm{l}$. Recombinant BMP2, BMP4 (Fig. 2), and SHH (200 ng/ $/ \mu \mathrm{l}$ ) are used to preload affi-gel agarose beads and FGF2, FGF3, and FGF4 $(100 \mathrm{ng} / \mu \mathrm{l})$ are used to preload heparin acrylic beads. These preloaded beads are incubated for $30 \mathrm{~min}$ at room temperature and then washed for 5-15 min in culture media before being transferred with a mouth-controlled capillary pipette on top of the explants. As controls, beads loaded with $0.1 \%$ BSA in PBS are used. The explants with beads are cultured in serum-free medium for $20 \mathrm{~h}$ and processed for in situ hybridization $(5,6)$, proliferation assays $(7)$, and immunohistochemistry $(6,8)$ as described in the references (see Note 13$)$.

3. Cell cocultures

The usage of cell cocultures for induction of ameloblastoma tissues allows exposing the tumors to a collection of factor the cells express in vitro. We use murine embryonic odontogenic cells (pre-ameloblasts or pre-odontoblasts) to determine the effect of each specific cell type on the explant. 


\section{Author's Proof}

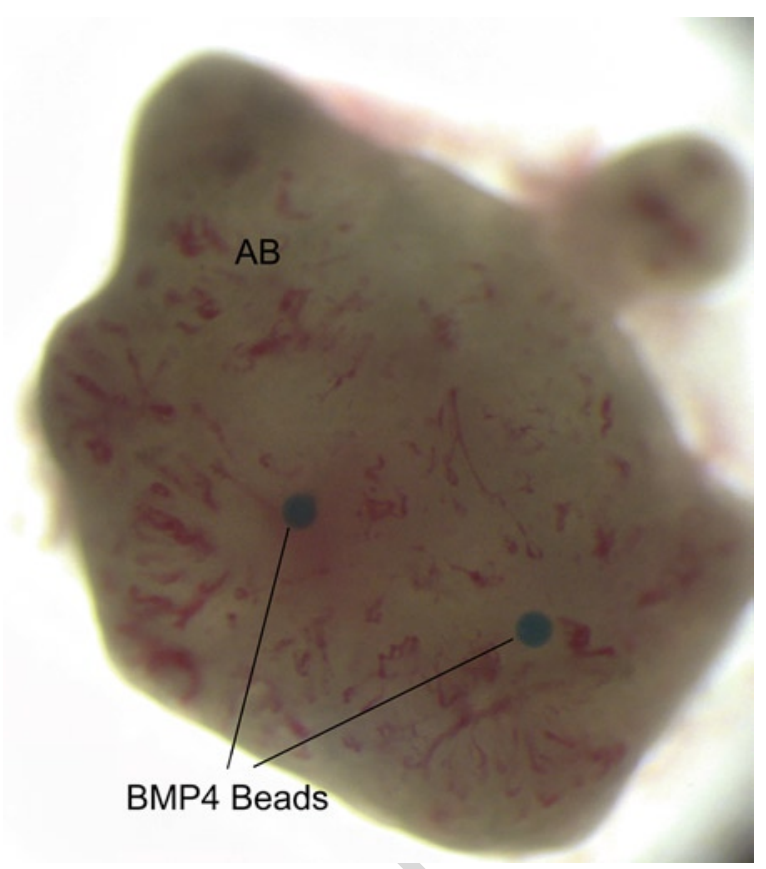

Fig. 2. Preloaded affi-gel agarose beads (BMP4 beads) implanted on top of an ameloblastoma (AB) organotypic culture.

Dissected first mandibular molars from El6.5 mouse (see

Note 14) are placed in $2.4 \mathrm{U} / \mathrm{ml}$ of Dispase and incubated for $\mathrm{l} \mathrm{h}$ at $4^{\circ} \mathrm{C}$. The mesenchymal tissue is mechanically separated from the epithelium using tungsten needles. The two tissues are placed separately in $0.25 \%$ trypsin at $37^{\circ} \mathrm{C}$ for $30 \mathrm{~min}$. Disaggregating is achieved by passing the cells after trypsin treatment through an 18 -g needle. The cell suspension is centrifuged and the pellet washed in DMEN with $1 \times$ pen/strep. The cells are centrifuged once more and the pellet is placed using a pipette tip in the ameloblastoma explants (Fig. 3). These explants are cultured in differentiation medium for up to 10 days. The cocultured explants are fixed and treated for study as described before.

\section{Monolayer cultures}

Cells are isolated from the fresh tissue using two methods:

Explants shedding allows cells to cast off from small tissue explants into a culture dish. The explants are cut in a similar way as the organotypic cultures. These explants are then placed in $10-\mathrm{cm}$ cell culture dishes with CnT24 media just covering the bottom of the dishes. This allows the explants to have an optimum gas exchange. The explants are kept in this culture conditions for approximately $\mathrm{l}$ week or when epithelial-like cell colonies are observed attaching to the culture dish. The tissue can also be digested in collagenase IV (freshly prepared 


\section{Author's Proof}

Fig. 3. GFP expressing odontogenic cells (GFP) placed on top of ameloblastoma (AB) explants in organotypic cocultures.

$500 \mathrm{CDU} / \mathrm{ml}$ ) at $37^{\circ} \mathrm{C}$ for $30 \mathrm{~min}$. The cells' disaggregation 282 is achieved by passing them through an 18-g needle. The cell 283 suspension is centrifuged and the pellet washed in DMEN with 284 $1 \times$ pen/strep. Centrifuge the cells once more and resuspend 285 the pellet in CnT24 medium for plating in culture dishes (see 286 Note 15).

Ameloblastoma cells can then be characterized for markers common with other epithelial stem cells and other tumor stem 289 cells. These markers can be detected by immunohistochemis- 290 try, in situ hybridization, or RT-PCR. For membrane-bound 291 markers, the cells can be shorted using fluorescence activated 292 cell sorting (FACS) (9). This allows separating living cells 293 expressing the marker of interest from the rest.

1. Chemicals are purchased commercially from your choice of 296 provider and solutions should be prepared nuclease free for 297 studies with the need for RNA preservation. 


\section{Author's Proof}

2. Liq N2 should be handled with extreme care and protective clothing, gloves, and eye shield should be worn.

3. $4 \%$ PFA aliquots can be stored long term at $-20^{\circ} \mathrm{C}$. Avoid repeated temperature change cycles and bring to near room temperature before use. It is recommended to use phosphate buffer made with nuclease-free water.

4. We also purchase molecular biology-grade $100 \times$ TE for nucleic acid work.

5. Histoclear is less toxic and the results are similar.

6. Dehydration of tissue for nucleic acid work-in situ hybridization-should be done with gradient alcohols made with nuclease-free water.

7. We normally received the tissue from the pathology department. They select a portion of the tumor and hand it to the research team on DMEM with Pen/Strep.

8. Most departments will have a tissue bank for storage of the tissue. This could be useful for in vivo studies.

9. The pathology department that provides the tissue will normally process it in this manner for routine histological analysis. These preparations could be used for morphological study of the tissue.

10. The tissue should sink to the bottom of the container to indicate a correct infiltration.

11. Rapid freezing is recommended, although we have observed that simply placing the mold in dry ice will freeze the sample quickly enough without any adverse effect. It is also possible to use dry ice and ethanol mixture to accelerate the freezing process.

12. If the cryostat has auto-sectioning mode, then one should slow the speed of sectioning (approx. $5 \mathrm{~mm} / \mathrm{s}$ ) to ease the manipulation of the sections as they are coming off the block face. Do not use the anti-roll plate furnished with the cryostat; it compresses the sections and results in poor tissue morphology.

13. In situ hybridization can be done on whole mount or cryosections.

14. We use mice expressing green fluorescent protein (GFP) in order to being able to distinguish the mouse cells from the tumor cells.

15. Epithelial cells are more likely to grow when plated in higher concentrations. 


\section{Author's Proof}

\section{References}

1. Barnes, L. et al. (2005) Pathology and Genetics of Head and Neck Tumours, IARC Press, Lyon.

2. Li, T. J. (2011) The odontogenic keratocyst: a cyst, or a cystic neoplasm? J Dent Res 90, 133-142.

3. Reichart, P. A., and Philipsen, H. P. (2003) [Revision of the 1992 edition of the WHO histological typing of odontogenic tumors. A suggestion], Mund Kiefer Gesichtschir 7, 88-93.

4. Trowell, O. A. (1954) A modified technique for organ culture in vitro, Exp Cell Res 6, 246-248.

5. Mitsiadis, T. A., Hirsinger, E., Lendahl, U., and Goridis, C. (1998) Delta-notch signaling in odontogenesis: correlation with cytodifferentiation and evidence for feedback regulation, Dev Biol 204, 420-431.

6. Mitsiadis, T. A., Salmivirta, M., Muramatsu, T., Muramatsu, H., Rauvala, H., Lehtonen, E., Jalkanen, M., and Thesleff, I. (1995) Expression of the heparin-binding cytokines, midkine $(\mathrm{MK})$ and HB-GAM (pleiotrophin) is associated with epithelial-mesenchymal interactions during fetal development and organogenesis, Development 121, 37-51.

7. Mitsiadis, T. A., Muramatsu, T., Muramatsu, H., and Thesleff, I. (1995) Midkine (MK), a heparin-binding growth/differentiation factor, is regulated by retinoic acid and epithelialmesenchymal interactions in the developing mouse tooth, and affects cell proliferation and morphogenesis, J Cell Biol 129, 267-281.

8. Mitsiadis, T. A., Dicou, E., Joffre, A., and 372 Magloire, H. (1992) Immunohistochemical 373 localization of nerve growth factor (NGF) and 374 NGF receptor (NGF-R) in the developing first 375 molar tooth of the rat, Differentiation 49, 376 47-61.

9. Mekada, E., Yamaizumi, M., and Okada, Y. 378 (1978) An attempt to separate mononuclear 379 cells fused with human red blood cell-ghosts 380 from a cell mixture treated with HVJ (Sendai 381 virus) using a fluorescence activated cell sorter 382 (FACS II), J Histochem Cytochem 26, 62-67. 383 


\section{Author's Proof}

\section{Author Queries}

Chapter No.: 15

0001507499

\begin{tabular}{|c|c|c|}
\hline Queries & Details Required & Author's Response \\
\hline AU1 & $\begin{array}{l}\text { Please check whether the edits made to the sentence "The classification of OTs most } \\
\text { used..." are ok. }\end{array}$ & \\
\hline AU2 & $\begin{array}{l}\text { Please check whether it should be "pried" instead of "prized" in the sentence "In } \\
\text { those OTs that expand the jaws...". }\end{array}$ & \\
\hline AU3 & $\begin{array}{l}\text { Please check whether it should be "DMEM" instead of "DMEN" in the sentence } \\
\text { "The cell suspension is centrifuged..."; comment applicable for all similar usages. }\end{array}$ & \\
\hline AU4 & $\begin{array}{l}\text { Please check whether the edits made to the sentence "These explants are then } \\
\text { placed..." are ok. }\end{array}$ & 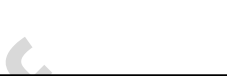 \\
\hline AU5 & Please check whether "(GFP)" should be deleted from the legend of the Fig. 3 . & 2 \\
\hline AU6 & $\begin{array}{l}\text { Please check whether the edits made to the sentence "We normally received the } \\
\text { tissue..." are ok. }\end{array}$ & \\
\hline AU7 & $\begin{array}{l}\text { Whom does the pronoun "They" implies in the sentence "They select a portion of } \\
\text { the tumor..."? Please check and make necessary changes to enhance understand- } \\
\text { ability. }\end{array}$ & \\
\hline
\end{tabular}

